Volume 27, 2017

http://journals.sfu.ca/cjsdw

Article

\title{
Locating Canadian Writing Centres: An Empirical Investigation
}

Pamela Bromley

Pomona College

\begin{abstract}
As writing centres in Canada face challenges to their existence, funding, and stature, it may be helpful to situate the Canadian experience empirically. This project investigates the number of, geographical, institutional, and physical locations of, and longevity of Canadian writing centres using information from an original database and survey examining writing centres located outside the United States. In the study, findings from Canada are compared to those from the United States, where the only other comprehensive investigations of writing centres have taken place. Results demonstrate that 123 writing centres in Canada are located in all 10 Canadian provinces as well as the Yukon territory, almost half of centres operate under the academic affairs umbrella of their university and are physically located in the library, and that while writing centres in Canada are newer, on average, than their U.S. peers, they may be located in proportionally more universities. Unfortunately, the changes Canadian writing centres are experiencing are not new, as writing centres have previously faced challenges to their existence and place in the university. However, information about the number, institutional and physical location, and longevity of Canadian writing centres may be useful to administrators as they advocate for and further develop their writing centres.
\end{abstract}

Keywords: Writing centres, Higher education, Census, Location

\section{Introduction}

As the very topic of this Special Section indicates, writing centres in Canada are facing substantial changes, with services at some campuses being established, re-envisioned, and even shut down. It may, then, be helpful to situate the Canadian experience in a larger context, both in comparison to writing centres in the United States and as part of the expansion of writing 
Volume 27, 2017

http://journals.sfu.ca/cjsdw

centres outside the United States. Indeed, Canadian writing centres are at the forefront of the expansion of writing centres outside the United States: writing centres in Canada seem to be the first established outside the United States (S. Mendelsohn, personal communication, 2 October 2016) and they are an important feature in Canadian higher education (Graves \& Graves, 2006; Procter, 2011). In addition to writing centres' core activities supporting students across all academic disciplines and educating professional and student staff about all aspects of their work with students, Canadian writing centre scholars are extraordinarily active in the field, sharing their research in books, edited volumes, and peer-reviewed journals (e.g., Eckstein, 2016; Estela Palomino \& Ferreira Gouveia, 2011; Graves \& Graves, 2006, 2011; Moussu, 2013; Procter, 2011). In many ways, Canadian writing centres are at the leading edge of writing centre practice, with a focus on writing in the disciplines, working with non-native English speakers, collaborating with libraries, and operating independently.

Writing centres, which began in the United States in the early $20^{\text {th }}$ century (Boquet, 1999; Lerner, 2009; S. Mendelsohn, personal communication, 2 October 2016), are growing in number outside that country (see, for example, the profiles of writing centres around the world in Thaiss, Bräuer, Carlino, Ganobsik-Williams, \& Sinha, eds., 2012). A census is one way to document basic information about the numbers and fundamental work of organizations, as it asks all institutions the same questions, allowing for clear, cross-institutional comparisons. A census can also illustrate growth and change, particularly if it is repeated. However, despite increased scholarly attention focused on the work of writing centres in Canada, comparative information about the work of writing centres there is lacking. Canada is not alone-this is the case for most countries, although the United States has made some progress documenting writing centres (Denny, 2015; National Census of Writing, 2017). In 2015-16, I conducted a census of writing centres located outside the United States, using, when possible, questions from the two U.S. surveys so that results could be compared. Below, I share a snapshot of writing centres across Canada, focused on how writing centres locate themselves in and outside their institutions.

\section{Methodology}

This project has two parts: a database of writing centres outside the United States - determined through Internet searches for writing centres - and a survey of professionals working in those centres. I began by creating a database of writing centres outside the United States using online 
Volume 27, 2017

http://journals.sfu.ca/cjsdw

searches. I searched: (1) the Writing Center Directory, (2) websites of non-U.S.-based International Writing Center Association (IWCA) affiliates for their members, and (3) every country in the world and Canadian provinces with the terms "writing center," writing centre," "writing lab," "learning center," "learning centre," and "academic resource." I completed this search in languages where I could decipher key information in a website: Danish, Dutch, English, French, German, Italian, Norwegian, Portuguese, Spanish, and Swedish. I then examined the search results, including in the database those centres that offered one-on-one, student-centered appointments, a centrepiece of writing centre practice (Kelly, 1980; Harris, 1988; Lerner, 2009; Grutsch McKinney, 2013) and excluding centres that did not include oneon-one appointments and only hosted workshops and courses. The first issue of The Writing Center Journal provides one rationale for this decision: Kelly (1980) notes that an enduring feature of her writing centre, which began in the 1930s, has been one-on-one conferences, while Harris and Yancey's article from this same issue notes that one-hour workshops are a new feature of writing labs. Of special interest for the Canadian context, all respondents to Bell and Hubert's (1996) survey of Canadian writing centres reported having one-on-one tutoring, providing another rationale. My understanding of writing centres as places where students receive individualized tutoring aligns with what Grutsch McKinney (2013) calls the "writing center grand narrative," the way that writing centre practitioners and those who come into contact with writing centres describe their work (p. 3). Grutsch McKinney goes on to complicate this grand narrative, underscoring that in "contemporary writing centers [...], writing center work exceeds appointment-based individualized instruction” (p. 8). Implicit in Grutsch McKinney's argument is that individualized instruction is the heart of writing centre work. Therefore, I focus here on centres that do that one-on-one work, acknowledging that many centres do this work and much more.

If the same institution had several writing centres, I included all of them; these centres usually served different groups of students on a single campus or different physical campuses of that institution. I completed my search in April 2015, arriving at a database that includes 123 writing centres from across Canada. The Canadian Writing Centres Association / L'Association Canadienne des Centres de Rédaction has a directory with current contact information for 142 writing centres in Canada - 19 more centres than I documented (CWCA/ACCR, 2016). I expect that some of the discrepancies between my data and the information from CWCA/ACCR are the result of differences in the ways that campus writing centres are counted, that my database does 
Volume 27, 2017

http://journals.sfu.ca/cjsdw

not include centres that do not host one-on-one appointments, and that the CWCA/ACCR list is one year newer.

In order to learn more about the work of these centres, I conducted an IRB-approved survey. The survey's 47 questions asked participants to share their contact information, as well as information about their centre's physical space, eligibility for services, available services, online services, institutional location, longevity, publicity, numbers and types of appointments, language use, staff and staff training, and their professional background and appointment. Questions were typically quantitative but there were a few opportunities for participants to share open-ended responses; I include the relevant survey questions in each section below. I sent the survey to email contacts for each writing centre in the database in May 2015, issuing one reminder; data collection closed in March 2016. From the 118 Canadian writing centres with working email addresses, I received 41 survey responses for a survey response rate of $33 \%$, a rate well in keeping with published studies targeted at organizations (Baruch \& Holtom, 2008).

Below, I often compare my Canadian database and survey findings with two sets of writing centre survey data from the United States. The comparison to the U.S. is made because writing centres seem to have originated in that country, and because there is similar survey data documenting writing centres there. First, I compare my findings to the raw data from the 201415 Writing Centers Research Project (WCRP) (Denny, 2015). Of the 346 institutions completing the WCRP, 16 were from outside the United States, making this a good, if somewhat imperfect, comparison. For simplicity, I refer to those institutions who completed the WCRP as U.S. institutions, recognizing that 16 of the 346 respondents are not U.S.-based. Second, I compare my findings to the 2013-14 National Census of Writing (National Census of Writing, 2017). The NCW collected data from writing programs at 680 four-year universities and 220 two-year colleges in the United States, including information about writing centres at those institutions; except where noted, I use four-year institution data for comparative purposes.

I note that it is not possible to generalize from my survey data to the whole population of Canadian writing centres, just as it is not possible to generalize from the centres that completed the WCRP or the NCW to all U.S. writing centres (for more on statistical comparisons, see Grutsch McKinney, 2015). However, it is still valuable to compare my findings focused on Canadian institutions to the findings from these U.S.-based studies, as these comparisons can at least give us a sense of how writing centres are located in their universities, and thus, how they are-and are not-positioned to be able to advocate for themselves. 
Volume 27, 2017

http://journals.sfu.ca/cjsdw

Investigating writing centres located outside the United States in this way has its limitations, of course. For example, a centre must have a website available in a limited set of languages to be included in the database and a working email address to have the opportunity to complete the survey (although 10\% of Canadian survey respondents reported that their writing centre did not have a website). Below, I share information collected from the 123 Canadian writing centres in the database, as well as information gathered from 41 survey participants, comparing findings when possible to data from the U.S.-based NCW and/or WCRP.

\section{Results and Discussion}

\section{Number of Writing Centres}

Scholars in Canada and the United States have examined the history of the creation of writing centres in their countries (for Canada, see, e.g., Graves \& Graves, 2006; Kearns \& Turner, 2008; Procter; 2011; for the U.S., see, e.g., Boquet, 1999; Carino, 1995; Lerner, 2009). The number of writing centres in Canada has been assessed most recently by the CWCA/ACCR (2016), which relies on centres sharing their contact information with the organization. The CWCA/ACCR's self-reported data lists 142 writing centres, from the writing centre at Acadia University in Nova Scotia to the writing centre at Yukon College in the Yukon Territory.

Using my database of writing centres outside the United States, I determine that there are 123 writing centres in Canada, including all writing centres on a single campus and at any branch campuses of a single institution. For example, the University of Alberta has several writing centres located on the main campus as well as one on a branch campus (Graves \& Graves, 2011, p. 214), a pattern I see throughout the database. Collapsing centres by physical campus, I find that there are writing centres located at 100 different campuses; 96 of these writing centres are located at institutions of higher education (including four two-year colleges). Dividing the number of university campuses with writing centres (96) by the number of institutions of higher education in Canada (146, according to Förster, 2016), I find that 66\% of Canadian institutions of higher education have writing centres. To put this growth in context, a 1996 survey of Canadian writing centres determined that there were 33 writing centers, using responses received from 107 contacted institutions. Kraglund-Gauthier (2006), who collected information through a listserv query, determined that there were at least 23 writing centres in Canada, while another review of Canadian writing centres that same year listed 49 (Schiopu, 
Volume 27, 2017

http://journals.sfu.ca/cjsdw

2006). It seems clear that Canadian writing centres have expanded considerably in number in the last two decades.

In the United States, the National Census of Writing (NCW) has attempted to comprehensively assess the number of writing centres operating there, finding that at least 881 institutions of higher education, including community colleges, report having writing centres (National Census of Writing, 2016). The NCW sent survey invitations to 2545 institutions of higher education in the U.S; $42 \%$ of four-year institutions and $24 \%$ of two-year institutions completed the survey. Of the 900 respondents to the survey (including two- and four-year institutions), 98\% reported having a writing centre; this very high percentage may very well be the result of selection bias-institutions that have a writing centre may have been much more likely to respond to a survey about writing than institutions that did not have a centre. Thanks to the NCW, we now know that at least 35\% of U.S. institutions of higher education have writing centres; that percentage may well be higher, given that a majority of institutions did not respond.

While the data collection methods for surveying U.S. and Canadian universities were quite different, it is intriguing that this information shows that a much higher percentage of Canadian universities (66\%) have writing centres than U.S. universities (35\%), given that writing centres began in the U.S. Part of this difference may be the result of the sheer number of universities in the U.S. and that the NCW's survey requires time to complete. Fewer universities in Canada may make collecting information more feasible. Still, writing centres in the U.S. date back to at least the 1930s (Lerner, 2009), with at least seven centres currently in existence dating their establishment back to that decade (S. Mendelsohn, personal communication, 2 October 2016; see also Kelly, 1980). However, the first writing centre in Canada was not established until 1964 at Innis College, followed by the establishment of the writing centre at York University in 1967, with only a few others established in the 1970s (Procter, 2011; Kraglund-Gauthier, 2006; S. Mendelsohn, personal communication, 2 October 2016). Given their fairly recent introduction into the higher education landscape, it is interesting to find that a large majority of Canadian universities have writing centres. 
Volume 27, 2017

http://journals.sfu.ca/cjsdw

\section{Geographic Location}

Knowing the number of Canadian writing centres is a helpful first step in understanding their place in their institutions. Information about writing centres' geographic location is another way to assess how they are distributed. Figure 1 visualizes Canadian writing centres by province.

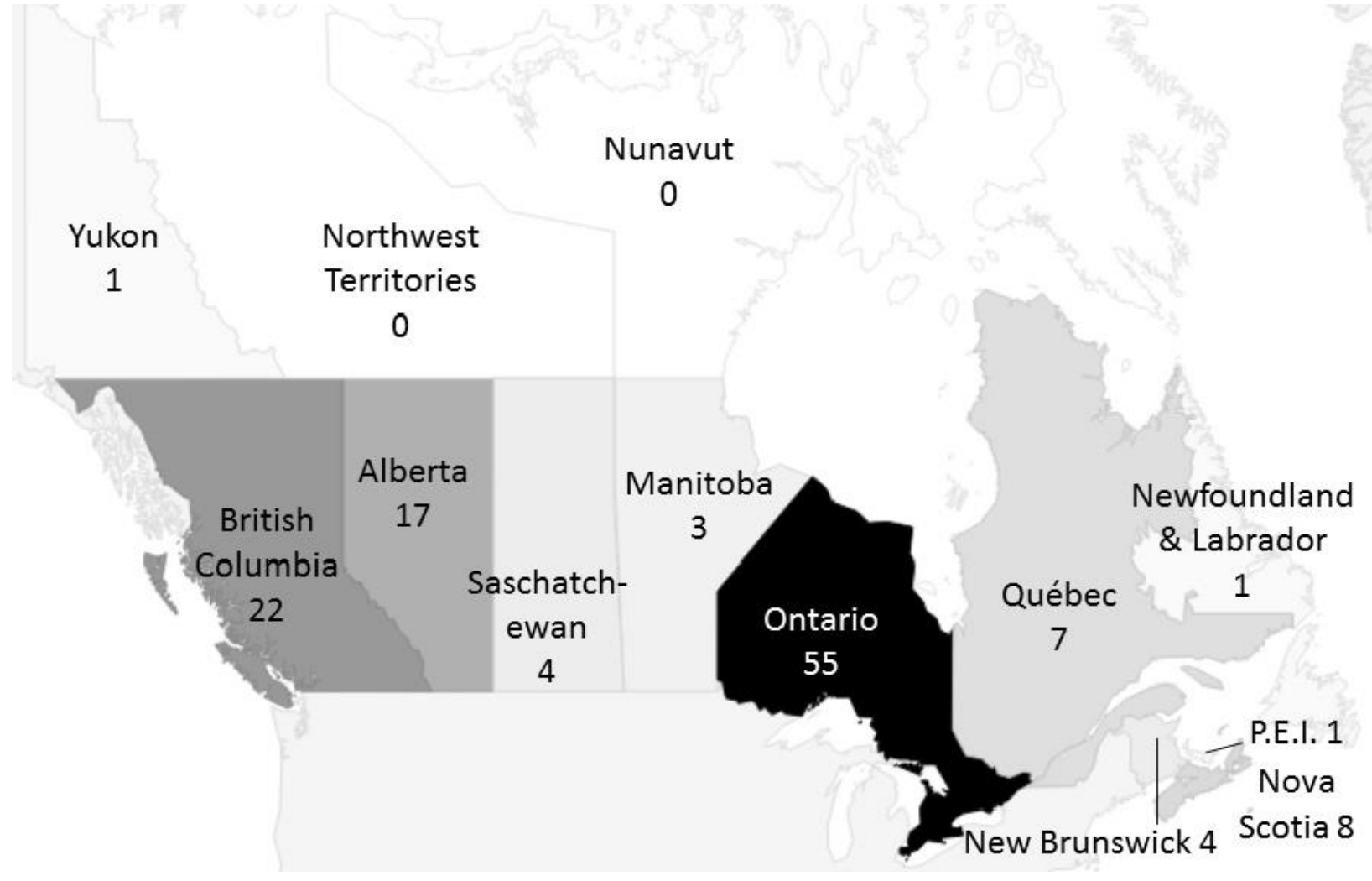

Figure 1. Distribution of Canadian Writing Centres by Province.

Writing centres are located in all ten Canadian provinces as well as the Yukon territory. Perhaps unsurprisingly, the largest number of writing centres is in Ontario, the province with the largest population, the most universities, and the first writing centres in the country (Procter, 2011; S. Mendelsohn, personal communication, 2 October 2016). The geographic distribution by province is interesting: Ontario, with $38 \%$ of the population, has $45 \%$ of writing centres, British Columbia has $13 \%$ of the population and $18 \%$ of writing centres, and Alberta has $12 \%$ of the population and $14 \%$ of writing centres, while Québec has just 6\% of writing centres even as the province has $23 \%$ of the population (population data from Statistics Canada, 2017). This disparity may stem from the origination of writing centres in the United States using English as language of instruction. Thus, perhaps writing centres, established in the Anglo- 
Volume 27, 2017

http://journals.sfu.ca/cjsdw

Canadian educational system for more than 40 years, are only slowly moving into the FrancoCanadian educational system. Roger Graves' (1994) study of writing instruction in English- and French-language Canadian universities notes that there was less writing instruction in Frenchlanguage universities than in their English-language counterparts, and while writing centres are mentioned as an important area of writing instruction in English-language universities, writing centres are not mentioned in the sections on French-language universities.

Most (94\% or 116) Canadian writing centres are located in four-year universities, with a few centres located at two-year colleges (4) and secondary schools (3). This distribution is quite similar to data from the United States. Of those institutions completing the 2014-15 WCRP, the vast majority (96\% or 333) of writing centres were located in institutions of higher education, including $11 \%$ (38) at two-year colleges, as well as centres at a dozen secondary schools, and one workplace. In Canada, I found writing centres located only in educational institutions, but within these institutions, there was real diversity: writing centres at two-year colleges, such as the one at Nova Scotia Community College; writing centres serving academic faculties, like the Engineering Communication Program at the University of Toronto Department of Engineering; bilingual writing centres, including from the Centre d'écriture bilingue at Campus St. Jean at the University of Alberta; and writing centres at secondary schools, such as the writing centre at St. Michael's University School in British Columbia.

\section{University Location}

Just as important as geographic location is the location of writing centres within the university. An essential aspect of any writing centre's institutional identity is its name. While some centres may have the opportunity to choose their own name, many centres' names may be designated by their institution. 45\% (or 55) of writing centres in Canada use "writing centre" in their name. Other common features of Canadian writing centre names include "learning" (16\%), "academic" (11\%), "support” (7\%), "services” (7\%), "student” (6\%), and "skills" (6\%).

Carino (1992) points out that centres' names are important acts of self-definition, reminding us that "we construct reality in language, but this recognition also accounts for the material conditions and political intentions inscribed in our constructions" (p. 31). The term "writing centre," has a built-in tension, evoking a sense of enclosed communality and camaraderie while at the same time being positioned at the centre of an academic institution, by providing one-onone tutoring as well as courses, and TA and faculty training. Positioning themselves at the centre 
Volume 27, 2017

http://journals.sfu.ca/cjsdw

of the institution by providing additional services may be problematic, as it takes writing centres away from their core mission of one-on-one sessions, and may allow them to be co-opted by their institutions (Carino, 1992, p. 38). When the term "skills center" is used, this can connote "a mechanistic model of parts being put together to make a whole" (Murphy, 1991, p. 277) which is seen by many in the institution "as a euphemism for clinic or lab" (Carino, 1992, p. 38), metaphors that signal a "marginal place where the marginal student attends to the teacher's marginal symbols on grammar errors" (p. 36). Thus, writing centres' names are an indication of how they position themselves and how others perceive their positions in their institutions. With almost a majority of centres using the term "writing centre," in their own names, Canadian centres locate themselves in a long tradition. For example, IWCA, the writing centre umbrella organization, and all of its regional, national, and international affiliates, all use "writing center" or "writing centre" in their own names (IWCA, 2016).

Moving beyond names, I also examined centres' administrative reporting lines, asking "to what larger unit do centres report?” Of the 29 Canadian centres responding to this question, $48 \%$ noted that they report to some area of academic affairs, most often a specific department (including rhetoric, humanities, and modern languages), or directly to an academic dean (including to a vice dean of Engineering, and to a dean of Arts). A third of centres (33\%) replied that they report to student affairs, most often to student services. The remaining $19 \%$ of centres responded that they report elsewhere in the university, most often the library.

The two U.S.-based surveys phrased this question in somewhat different ways. The NCW asked, "is the writing centre free-standing or part of a larger institutional unit?" $39 \%$ of respondents reported that their centre was free-standing, while the remaining $61 \%$ noted that their centre was part of a larger unit. Centres that were not free-standing were then asked "what larger institutional unit is it a part of?" These centres most often reported to an academic department or program (36\%) or a learning centre or learning commons (27\%). The WCRP asked centres "what is your center's departmental/program affiliation?," giving respondents the ability to check multiple options; $48 \%$ of centres noted that they are affiliated with a specific academic department or program, 36\% replied that they are affiliated with a learning centre or student services, and 20\% reported that they are independent.

Canadian centres, like U.S. centres, most often are affiliated with academic departments or report directly to a dean; almost half of centres are located in academic affairs. Centres in both countries are likely to affiliate with student services; according to this study, the NCW, and the WCRP, about a third of centres are located in student services. There is a strong desire in 
Volume 27, 2017

http://journals.sfu.ca/cjsdw

Canadian centres to underscore the intellectual and academic work that takes place in writing centres, perhaps because there is anxiety about their placement, permanence, and position on campus (Procter, 2011, p. 415). Locating a writing centre in student affairs may give the impression that the writing center is simply an amenity provided to students, rather than a pedagogy promoting students' academic growth and learning.

\section{Physical location}

In addition to understanding a centre's institutional location, knowing a centre's campus location is essential, as physical location by definition reflects the position of that entity within the larger institution (Haviland, Fye, \& Colby, 2001). While a centre's physical location does not determine where it reports, a centre's physical location does provides a clear indication of its institutional position, whether central or marginal, academic or service. The survey asked respondents to respond this question: "Where is your center physically located on campus?" The 40 institutions completing this survey question are located in a wide range of places on campus.For Canadian writing centres, the most common campus location is libraries (44\%), distantly followed by other locations (26\%), classroom buildings (16\%), and learning or student centres (6\%). A centre's reporting line is by no means an indicator of a centre's physical presence, as just $16 \%$ of centres are located in classroom buildings, even as $48 \%$ of centres note that they report administratively to some part of academic affairs.

This distribution stands in contrast to the physical locations of writing centres in the U.S., where the greatest number of centres are located in classroom buildings (39\% according to the smaller WCRP and 52\% according to the larger NCW), followed closely by libraries (36\% according to the WCRP and 45\% according to the NCW). No Canadian universities reported a writing centre in a residential location, while $6 \%$ of centres in the NCW did so. Individual writing centres sometimes have satellite locations. This was true for $18 \%$ of Canadian centres; $14 \%$ of centres in the NCW reported satellite locations, as did $38 \%$ of centres responding to the WCRP. Thus, in Canada and the United States, writing centres around the world are becoming "de-centered," that is, located in multiple locations across individual campuses, as predicted by Kinkead and Harris (2000, p. 23).

The location of most Canadian centres in the library, rather than in classroom buildings, may speak to the historical legacy of Canadian writing centres lacking a departmental home (Kearns \& Turner, 2008). Perhaps the administrative reporting line, in many cases, is something of an 
Volume 27, 2017

http://journals.sfu.ca/cjsdw

artifact, put in place for convenience and not because it shows a real affiliation. Indeed, it may well be that, precisely because writing centres lack a departmental home and therefore must advocate for themselves and for the importance of writing across the university, Canadian centres are able to "raise awareness of writing issues" throughout their universities (Procter, 2011, p. 416).

Information about the size of a centre's physical space is also a helpful indicator of a centre's importance (or lack thereof) on campus. Respondents were asked, "What is the physical size of the writing center?" Canadian centres are likely to be somewhat smaller than their U.S. peers, with $33 \%$ of Canadian centres with $40 \mathrm{~m} 2$ / $430 \mathrm{ft} 2$ of space or less (the size of a spacious studio apartment), compared to $21 \%$ for U.S. centres. U.S. centres are likely to have more space than their Canadian peers $-41 \%$ of centres in the U.S. have $80 \mathrm{~m} 2 / 860 \mathrm{ft} 2$ or more (the size of a small house or larger), compared to $18 \%$ of Canadian centres. Of the 40 Canadian centres reporting on space adequacy, 62\% report that their space is adequate or mostly adequate for their needs, while $38 \%$ note that their space is mostly or definitely inadequate for their needs. The lack of physical space in some Canadian centres may be an indication of their lack of prominence in their universities.

\section{Longevity}

Exploring the longevity of institutions simply means determining whether they have persisted in a specific location over a period of time. The reason to care about longevity-the reason that Lerner (2009) "search[ed] for the first writing laboratory" (p. 8)-is to learn more about why writing centres were established and what goals they were meant to achieve, that is, "for what problem were writing centers proposed as the solution" (p. 15). Table 1 compares the longevity of writing centres in Canada and the United States, reflecting on how long an institution has had a writing centre in any form. Both my survey and the WCRP asked the same question: "How many years has your institution had some form of a writing center?" Both surveys allowed for participants to share the number of years or leave a more extensive comment. Canadian centres are somewhat newer than U.S. centres. For example, while $39 \%$ of Canadian centres have existed for 10 years or fewer, just $22 \%$ of U.S. centres are that new. On the flip side, $26 \%$ of U.S. centres are over 30 years old, true of only $9 \%$ of Canadian centres.

This survey data reflects conversations about the longevity of writing centres in both Canada and the U.S. The first article of the first issue of Writing Center Journal features an article 
Volume 27, 2017

http://journals.sfu.ca/cjsdw

written about the writing lab at the University of Iowa (Kelly, 1980). That Writing Center Journal sought, in its inaugural issue, to report on the history of a venerable institution says a great deal about the importance that writing centres place on their long history. Kelly's article reports on the 35-year history the University of Iowa's Writing Lab, examining its many changes: from required visits for "students whose placement themes did not meet departmental standards" (p. 5); to teaching writing as "a communication skill, not communication" (p. 10, original emphasis); to a writing lab that sees a wide range of student with diverse backgrounds, from graduate students to first-years, helping them "become better writers" (p. 14). Scholarship focused on the history of writing centres in the U.S. likewise reflects on the importance of the early roots of writing centres (e.g., Boquet, 1999; Carino, 2003; Lerner, 2003; Lerner, 2009).

Table 1. Longevity of Canadian and U.S. Writing Centres

\begin{tabular}{lcc}
\hline Length of time & $\begin{array}{c}2015-16 \text { Canadian WCs } \\
(\mathrm{n}=33)\end{array}$ & $\begin{array}{c}2014-15 \text { WCRP } \\
(\mathrm{n}=229)\end{array}$ \\
\hline 5 years or fewer & $15 \%$ & $9 \%$ \\
$6-10$ years & $24 \%$ & $13 \%$ \\
$11-20$ years & $30 \%$ & $22 \%$ \\
$21-30$ years & $21 \%$ & $27 \%$ \\
$31-40$ years & $6 \%$ & $21 \%$ \\
More than 40 years & $3 \%$ & $5 \%$ \\
Don't know & $\mathrm{n} / \mathrm{a}$ & $3 \%$ \\
\hline
\end{tabular}

Scholars in Canada have likewise been interested in examining the longevity of their writing centers. Procter (2011) notes that, with the establishment of the writing centre at Innis College in 1964, the University of Toronto "was among the earliest adopters of the writing-centre model in Canada, and it faced, from the start, the full range of issues in defining and defending that work" (p. 418). Wendy Kraglund-Gauthier, on the 10th anniversary of the establishment of the writing centre at St. Francis Xavier University in Nova Scotia, sought to learn "just how old are writing centres in Canada?" (2006). Asking this question on the Canadian Association for the Study of Language and Learning (CASLL) listserv, Kraglund-Gauthier received responses from 23 centres: seven centres reported being established in the 1970s, six in the 1980s, nine in the 
Volume 27, 2017

http://journals.sfu.ca/cjsdw

1990s, and one in the early 2000s. The investigation of the history of writing centres in a given country allows scholars and practitioners to better understand where their writing centres are coming from, to better articulate their work and their vision.

Of particular interest for this piece are comments about uncertainty and change in writing centres in both Canada and the U.S., as evidenced from qualitative responses to my survey and to the WCRP. Many respondents shared approximate dates: "about 8 years," "over twenty years," and "approx. 38 years" from Canadian respondents; "several," "over ten years," and "decades" from U.S. respondents. These responses show that not all centres have a clear sense of their own past history. Remarks about growth and change were quite common in survey responses. Canadian respondents commented variously that their centre had been operating "intermittently since 2005," and that "service has grown continuously over a 12-year period." Canadian centres were asked a follow-up question about continuity, also allowing for respondents to share numbers or more detailed information: "how many years has your writing center been operating in its current form?" There were a wide range of responses, with institutions reporting they have been operating in a new configuration for only one to two years, for eight years "with many variations but the same core services," to "form the same, but location changed," to 30 years without comment. These reports highlight that grappling with change often seems to be part of writing centre life.

\section{Conclusion}

Instruction in writing and rhetoric in Canada has developed in large part as a reaction against the U.S. model. As Hunt (2006) notes, “there's nothing remotely resembling the situation in the U.S., where most universities have offered, for many decades, mammoth programs designed to administer writing instruction to either all or most of their first year students" (p. 371). Canadian English programs historically excluded courses explicitly focused on writing, with writing incorporated in literature courses; "generally, instruction in writing existed only as marginal notations in student essays focused on literary works" (Hubert, 1994, p. 1). While there is some movement in Canadian universities to bring explicit instruction in writing into English departments, movement in this direction is slow (Brooks, 2006, pp. 114-15). As a result, writing instruction in English departments is often seen as a means to better understand and appreciate literary works, especially British literature (Kearns \& Turner, 2008, pp. 3-4). Much writing instruction in Canada takes place outside English departments, in arts and humanities, 
Volume 27, 2017

http://journals.sfu.ca/cjsdw

communications, education, linguistics, agriculture, engineering, and in law and business schools (Clary-Lemon, 2009; Graves, 1994). Canadian opposition to the U.S. model of writing and rhetoric instruction is particularly striking as the United States currently possesses the world's "most powerful academic system . . . [and has] pioneered academic thinking and curricular trends" in higher education (Altbach, Reisberg, \& Rumbley, 2009, p. 17). Importantly, the Canadian tradition of writing instruction "offers administrative structures, program design, and pedagogical features that constitute interesting alternative approaches to the traditional first-year writing programs established at most American universities" (Graves \& Graves, 2006, p. 2). For example, U.S. writing scholars could learn a great deal from the important work being done by their Canadian colleagues in technical and professional communication and other disciplines across the university (Clary-Lemon, 2009; Graves \& Graves, 2006), as well as the benefits and challenges of operating without a departmental home (Hunt, 2006; Procter, 2011).

Writing centres are something of an exception to the pushback against U.S. models seen in most Canadian writing instruction. Kearns and Turner point out that writing centres are "the area in which Canadian universities have been most like their American counterparts" (2008, p. 6). In fact, faculty working in these programs have "almost universally been trained" in U.S.based rhetoric and composition programs (Hunt, 2006, p. 374). However, writing centres in Canada remain within the country's broader framework of writing instruction, which "fit[s] nowhere else in the traditional departmental and administrative structure of universities" (Hunt, 2006, p. 376) and where writing is often seen as "service" provided to the university. The result that writing centres are "often under-funded, located in Student Services or libraries, operating without departmental status or tenured faculty, and misunderstood by faculty and students" (Kearns \& Turner, 2008, p. 6), often having to make a yearly case for funding and therefore prone to crisis or closure (Proctor, 2011).

Growth, contraction, and change are core, if sometimes contradictory, features in writing centers, and these features are not new. For example, in the U.S., there was a precipitous decline in writing clinics by 1960, following a rapid post-WWII expansion (Lerner, 2003). U.S. writing centres again faced a crisis in the 1970s, with the shift to open admissions (Boquet, 1999). In Canada, a 1990 s crisis was prompted by the introduction of technology that was intended to "replace" writing tutors, in addition to concerns about faculty contract length, title, and appointment location (Procter, 2011, p. 420). Recently, there have been movements to close, threaten, or restructure writing centres across the country, including at institutions as diverse as the University of British Columbia (McCabe, 2016a; McCabe, 2016b), the University of the 
Volume 27, 2017

http://journals.sfu.ca/cjsdw

Fraser Valley (Olsen, 2015), the University of Alberta (Moussu, 2016a; Moussu 2016b), and Wilfred Laurier University (Paul, 2015).

Sometimes a moment of crisis might not save a program but might spur action elsewhere, as happened when Scarborough College opted to replace writing lab instruction with computers and software, prompting a broad response from writing tutors at the University of Toronto, ultimately resulting in a considerable expansion in numbers and staffing of writing labs (Procter, 2011). While this historical context may not address the current challenges faced by Canadian writing centres-and, indeed, all writing centres-it may be helpful to know that these concerns have previously been faced. In fact, these worries are currently being felt by centres around the world, as I have found in responses to my survey from Canada as well as many other countries. Knowing more about the current numbers, institutional and geographical locations, and longevity of writing centres across Canada may provide useful information for administrators seeking to fight for their centre's existence or place in the university or to expand their centre's role in the university and beyond.

\section{References}

Altbach, P. G., Reisberg, L., \& Rumbley, L. E. (2009). Trends in global higher education: Tracking an academic revolution. Report prepared for the UNESCO 2009 World Conference on Higher Education. UNESCO and World Conference on Higher Education. Paris: UNESCO.

Baruch, Y., \& Holtom, B. C. (2008). Survey response rate levels and trends in organizational research. Human Relations, 61(8), 1139-1160.

Bell, S., \& Hubert, H. (1996). University College of the Cariboo national writing centre survey. Inkshed Newsletter, 14(6). Retrieved from http://www.inkshed.ca

Boquet, E. H. (1999). "Our little secret": A history of writing centers, pre-to post-open admissions. College Composition and Communication, 5o(3), 463-482.

Canadian Writing Centres Association/L’Association Canadienne des Centres de Rédaction (CWCA/ACCR) (2016). Contact list. Retrieved from https://casdw-acr.ca

Carino, P. (1995). Early writing centers: Toward a history. Writing Center Journal, 15(2), 103115 .

Carino, P. (1992). What do we talk about when we talk about our metaphors: A cultural critique of clinic, lab, and center. Writing Center Journal, 13(1), 31-42. 
Volume 27, 2017

http://journals.sfu.ca/cjsdw

Clary-Lemon, J. (2009). Shifting tradition: Writing research in Canada. American Review of Canadian Studies 39(2), 94-111.

Denny, H. (2015). Raw data 2014-15. Writing Centers Research Project Survey. Retrieved from https://owl.english.purdue.edu

Eckstein, G. (2016). Grammar correction in the writing centre: Expectations and experiences of monolingual and multilingual writers. Canadian Modern Language Review, 72(3), 360-382.

Estela Palomino, N., \& Ferreira Gouveia, P. (2011). Righting the academic paper: A collaboration between library services and the writing centre in a Canadian academic setting. New Library World, 112(3/4), 131-140.

Förster, K. (2016, 28 July). Universities worldwide. Retrieved from_http://univ.cc/world.php

Graves, R. (1994). Writing instruction in Canadian universities. Winnipeg, MB: Inkshed Publications.

Graves, R., \& Graves, H. (Eds.). (2006). Writing centres, writing seminars, writing cultures: Writing instruction in Anglo-Canadian universities. Winnipeg, MB: Inkshed Publications.

Graves, R., \& Graves, H. (2011). Writing programs worldwide: One Canadian perspective. In C. Thaiss, G. Bräuer, P. Carlino, L. Ganobcsik-Williams, \& A. Sinha (Eds.), Writing programs worldwide: Profiles of academic writing in many places (pp. 117-127). Fort Collins, CO: WAC Clearinghouse and Anderson, SC: Parlor Press.

Grutsch McKinney, J. (2013). Peripheral visions for writing centers. Boulder, CO: Utah State University Press.

Grutsch McKinney, J. (2015). Strategies for writing center research. Anderson, SC: Parlor Press.

Harris, M. (1988). SLATE (Support for the learning and teaching of English) statement: The concept of a writing center. Urbana, IL: National Council of Teachers of English. Retrieved from http://writingcenters.org/

Harris, M., \& Yancey, K. B. (1980). Beyond freshman comp: Expanded uses of the writing lab. Writing Center Journal, 1(1), 41-49.

Haviland, C. P., Fye, C. M., \& Colby, R. (2001). The politics of administrative and physical location. In J. V. Nelson, \& K. Evertz (Eds.), The politics of writing centers (pp. 85-98). Portsmouth, NH: Boynton/Cook Publishers-Heinemann.

Hubert, H. A. (1994). Harmonious perfection: The development of English studies in nineteenth-century Anglo-Canadian colleges. East Lansing, MI: Michigan State University Press. 
Volume 27, 2017

http://journals.sfu.ca/cjsdw

Hunt, R. (2006). Afterword: Writing under the curriculum. In R. Graves \& H. Graves (Eds.). Writing centres, writing seminars, writing cultures: Writing instruction in Anglo-Canadian universities (pp. 371-83). Winnipeg, MB: Inkshed Publications.

International Writing Centers Association. (2016). Affiliate organizations. Retrieved from http://writingcenters.org

Kearns, J. \& Turner, R. (2008, 1 July). The historical roots of writing instruction in AngloCanadian universities. Zeitschrift Schreiben. Retrieved from http://zeitschrift-schreiben.eu

Kelly, L. (1980). One-on-one, Iowa City style: Fifty years of individualized writing instruction. Writing Center Journal, 1(1), 4-19.

Kinkead, J., \& Harris, J. (2000). What's next for writing centers? Writing Center Journal, $2 O(2), 23-24$.

Kraglund-Gauthier, W. (2006). So, just how old are writing centres in Canada? Inkshed. 23(1). Retrieved from http://www.stu.ca/inkshed

Lerner, N. (2009). The Idea of a writing laboratory. Carbondale, IL: Southern Illinois University Press.

Lerner, N. (2003). Punishment and possibility: Representing writing centers, 1939-1970. Composition Studies, 31(2), 53-72.

McCabe, S. (2016a, March 14). UBC writing centre to shut down tutorial services. The Ubyssey. Retrieved from https://www.ubyssey.ca

McCabe, S. (2016b, March 31). University to find new place for writing centre tutorial services. The Ubyssey. Retrieved from https://www.ubyssey.ca

McCallum, R. (2016, September 13). Graduate writing services. Retrieved from http://www.lib.sfu.ca/about/branches-depts/rc/services/writing-services

Moussu, L. (2013). Let's talk! ESL students' needs and writing centre philosophy. TESL Canada Journal, 3o(2), 55-68.

Moussu, L. (2016a, April 22). Sad news from the University of Alberta. Message posted to EATAW electronic mailing list. Retried from https://www.jiscmail.ac.uk

Moussu, L. (2016b, June 5). Update on a no longer sad story. Message posted to EATAW electronic mailing list. Retried from https://www.jiscmail.ac.uk

Murphy, C. (1991). Writing centers in context: Responding to current educational theory. In R. Wallace, \& J. Simpson (Eds.), The Writing Center: New Directions (pp. 276-288). New York: Garland Publishing. 
Volume 27, 2017

http://journals.sfu.ca/cjsdw

National Census of Writing. (2017). Four year institution survey [Data file]. Retrieved from https://writingcensus.swarthmore.edu

National Census of Writing. (2017). Two year institution survey [Data file]. Retrieved from https://writingcensus.swarthmore.edu

Olsen, T. (2015, February 28). UFV students rally against Writing Centre changes. Abbotsford News. Retrieved from http://www.abbynews.com

Paul, G.. (2015, March 11). Laurier faculty members feel 'absolutely gutted' by staff cuts. The Record. Retrieved from http://www.therecord.com

Procter, M. (2011). Talking the talk and walking the walk: Establishing the academic role of writing centres. In D. Starke-Meyerring, A. Paré, N. Artemeva, M. Horne, \& L. Yousoubova (Eds.), Writing in knowledge societies (pp. 415-439). Fort Collins, CO: WAC Clearinghouse.

Schiopu, B. (2006, March 29). Writing centres directory. Retrieved from http://english4pleasure.wikispaces.com

Statistics Canada. (2017, February 6). Population and dwelling count highlight tables, 2016 census. Retrieved from http://www12.statcan.gc.ca

Thaiss, C., Bräuer, G., Carlino, P., Ganobcsik-Williams, L., \& Sinha, A. (Eds.). (2012). Writing programs worldwide: Profiles of academic writing in many places. Fort Collins, CO/Anderson, SC: The WAC Clearinghouse and Parlor Press.

Writing Center Directory. Retrieved from http://web.stcloudstate.edu/ 